\title{
Acinetobacter rudis sp. nov., isolated from raw milk and raw wastewater
}

\author{
Ivone Vaz-Moreira, ${ }^{1,2}$ Ana Novo, ${ }^{1}$ Elionora Hantsis-Zacharov, ${ }^{3}$ \\ Ana Rita Lopes, ${ }^{2}$ Margarita Gomila, ${ }^{4}$ Olga C. Nunes, ${ }^{2}$ \\ Célia M. Manaia ${ }^{1}$ and Malka Halpern ${ }^{3}$ \\ ${ }^{1}$ CBOF - Escola Superior de Biotecnologia, Universidade Católica Portuguesa, 4200-072 Porto, \\ Portugal \\ ${ }^{2}$ LEPAE - Departamento de Engenharia Química, Faculdade de Engenharia, Universidade do Porto, \\ 4200-465 Porto, Portugal \\ ${ }^{3}$ Department of Biology and Environment, Faculty of Natural Sciences, University of Haifa, Oranim, \\ Tivon 36006, Israel \\ ${ }^{4}$ Unidad de Investigación-Microbiología, Fundación Hospital Son Llàtzer, 07198 Palma de Mallorca, \\ Illes Balears, Spain
}

Correspondence

Célia M. Manaia

cmmanaia@esb.ucp.pt
Two bacterial strains, $\mathrm{G} 30^{\top}$ and $\mathrm{A} 1 \mathrm{PC} 16$, isolated respectively from raw milk and raw wastewater, were characterized using a polyphasic approach. Chemotaxonomic characterization supported the inclusion of these strains in the genus Acinetobacter, with Q-8 and Q-9 as the major respiratory quinones, genomic DNA $\mathrm{G}+\mathrm{C}$ contents within the range observed for this genus (38-47 mol\%) and $\mathrm{C}_{16: 0}, \mathrm{C}_{18: 1} \omega 9 \mathrm{c}$ and $\mathrm{C}_{16: 1} \omega 7 \mathrm{c} / \mathrm{iso}-\mathrm{C}_{15: 0} 2-\mathrm{OH}$ as the predominant fatty acids. The observation of $16 \mathrm{~S}$ rRNA gene sequence similarity lower than $97 \%$ with other Acinetobacter species with validly published names led to the hypothesis that these isolates could represent a novel species. This hypothesis was supported by comparative analysis of partial sequences of the genes $r p o B$ and gyrB, which showed that strains $G 30^{\top}$ and $A 1 P C 16$ did not cluster with any species with validly published names, forming a distinct lineage. DNA-DNA hybridizations confirmed that the two strains were members of the same species, which could be distinguished from their congeners by several phenotypic characteristics. On the basis of these arguments, it is proposed that strains $\mathrm{G} 30^{\top}$ and $\mathrm{A} 1 \mathrm{PC} 16$ represent a novel species, for which the name Acinetobacter rudis sp. nov. is proposed. The type strain is strain G30 ${ }^{\top}$ (=LMG $26107^{\top}$ $=$ CCUG $57889^{\top}=$ DSM $24031^{\top}=$ CECT $7818^{\top}$ ).
Reflecting their ubiquity and metabolic versatility, bacteria of the genus Acinetobacter have been isolated from environmental sources as diverse as, for example, human and animal clinical samples, activated sludge and seawater (Carr et al., 2003; Juni, 2005; Nemec et al., 2009; Vaneechoutte et al., 2009). Some Acinetobacter species are also psychrotolerant, as demonstrated by their occurrence in low-temperature habitats such as frozen vegetables and fish products (Gennari \& Stegagno, 1985, 1986) or refrigerated raw milk (Uraz \& Çitak, 1998; Munsch-Alatossava \& Alatossava, 2006; Hantsis-Zacharov \& Halpern, 2007). At the time of writing, the diversity of this genus supported the definition

The GenBank/EMBL/DDBJ accession numbers for the 16S rRNA, $r p o B$ and gyr $B$ gene sequences of strains $G 30^{\top}$ and $A 1 P C 16$ are respectively EF204258 and FN298236 (16S rRNA gene), FN393751 and FN393750 (rpoB) and FN597721 and FN597720 ( gyrB).

Two supplementary tables are available with the online version of this paper. of 22 validly published species names (Euzéby, 1997). The current work characterized two bacterial strains of the genus Acinetobacter, $\mathrm{G}_{3}{ }^{\mathrm{T}}$ and $\mathrm{A} 1 \mathrm{PC} 16$, which were respectively isolated from raw milk and raw wastewater in independent studies in locations separated by more than $4000 \mathrm{~km}$ (Hantsis-Zacharov \& Halpern, 2007; Novo \& Manaia, 2010). This curious observation, allied with the fact that neither of the isolates could be identified as a member of any Acinetobacter species with a validly published name, motivated the present study, which aimed at comparing the two organisms and characterizing a presumed novel species.

Strain $\mathrm{G} 30^{\mathrm{T}}$ was isolated in northern Israel from raw milk, on plate count agar (PCA; Pronadisa), during a study of the seasonal dynamics of culturable psychrotolerant communities in that product (Hantsis-Zacharov \& Halpern, 2007). Strain A1PC16 was isolated in northern Portugal from raw wastewater on PCA supplemented with $4 \mathrm{mg}$ ciprofloxacin 
$1^{-1}$ during a study on antibiotic resistance prevalence in municipal wastewater (Novo \& Manaia, 2010). Both strains were purified by subculturing and maintained on PCA. Cultures were incubated at $30{ }^{\circ} \mathrm{C}$ and cryopreserved at $-80{ }^{\circ} \mathrm{C}$ in nutrient broth supplemented with $15 \%(\mathrm{v} / \mathrm{v})$ glycerol.

Although limitations of the 16S rRNA gene sequence to discriminate species are recognized within some genera, analysis of this gene is still a method of choice to infer relationships at the genus level, and this was our first approach. The following type strains that presented more than $95 \% 16 \mathrm{~S}$ rRNA gene sequence similarity with the isolates under study were included in the phenotypic comparison: Acinetobacter baumannii CCUG $19096^{\mathrm{T}}$, A. baylyi CCUG $50765^{\mathrm{T}}$, A. bereziniae LMG $1003^{\mathrm{T}}$, A. calcoaceticus CCUG $12804^{\mathrm{T}}$, A. guillouiae LMG $988^{\mathrm{T}}$, A. johnsonii CCUG $19095^{\mathrm{T}}$, A. junii CCUG $889^{\mathrm{T}}$, A. radioresistens CCUG $56440^{\mathrm{T}}$ and A. venetianus CCUG $45561^{\mathrm{T}}$.

Colony and cell morphology, the Gram-stain reaction, cytochrome $c$ oxidase and catalase activities and motility were analysed based on the methodologies of Murray et al. (1994) and Smibert \& Krieg (1994). Unless otherwise stated, all biochemical and physiological tests were performed as described by Vaz-Moreira et al. (2007). Phenotypic profiling was performed, using the API 20E, API 20NE, API 32GN and API ZYM panels (bioMérieux), following the instructions of the manufacturer, and the results were observed after $48 \mathrm{~h}$. To confirm the results obtained for the assimilation of sole carbon sources, assimilation of Dglucose, L-proline, L-alanine, L-histidine, L-arabinose, lactic acid, propionic acid, sodium citrate and valeric acid was also tested in the basal mineral medium of Cruze et al. (1979) supplemented with $0.1 \%(\mathrm{w} / \mathrm{v})$ of each carbon source as described by Nemec et al. (2009). Additionally, the carbon sources L-arginine, putrescine, ethanol, 2,3-butanediol, Laspartic acid, L-leucine, L-phenylalanine, sodium benzoate and histamine, which are not available in the commercial panels referred to above, were tested under these conditions. Simmons' citrate was tested on Simmons' citrate agar (Pronadisa), incubated for $48 \mathrm{~h}$ at $30{ }^{\circ} \mathrm{C}$. Aerobic acid production from glucose was tested with the Hugh \& Leifson OF basal medium (Pronadisa). Haemolytic activity was tested on Columbia agar with $5 \%$ sheep blood (bioMérieux).

For cellular fatty acid analysis, strains were cultured on tryptic soy agar (Difco) for $24 \mathrm{~h}$ at $28^{\circ} \mathrm{C}$ and the fatty acids were extracted and methylated as described by Ben-Ze'ev et al. (2005). Fatty acid methyl esters were analysed by gas chromatography using the MIDI/Hewlett Packard Microbial Identification System (Analytical Services Inc.). The $\mathrm{G}+\mathrm{C}$ content of genomic DNA and the respiratory quinones were analysed as described previously (VazMoreira et al., 2007), using the methods of Mesbah et al. (1989) and Tindall (1989), respectively.

Genomic DNA was isolated according to the method of Marmur (1961). DNA-DNA hybridizations were performed, in duplicate, using a non-radioactive method, as described by Ziemke et al. (1998). DNAs of strain $\mathrm{G} 30^{\mathrm{T}}$ and A1PC16 were double-labelled with DIG-11-dUTP and biotin-16-dUTP, using a nick translation kit (Boehringer Mannheim). Each labelled DNA was hybridized against itself and, as a control, against DNA from A. baylyi CCUG $50765^{\mathrm{T}}$.

The nucleotide sequence of the nearly complete 16S rRNA gene (1500 and $1489 \mathrm{bp}$ for strains $\mathrm{G} 30^{\mathrm{T}}$ and A1PC16) was determined after PCR amplification from genomic DNA extracts, as described previously (Ferreira da Silva et al., 2007; Hantsis-Zacharov \& Halpern, 2007). The region Z1$\mathrm{Z} 2$ of the $r p o B$ gene was examined as described before (La Scola et al., 2006). The gyrB gene was amplified with primers APRU-F/UP1E-R and sequenced with primers M13R/ M13(-21) (Yamamoto et al., 1999), in the following reaction mixture: $2 \mathrm{U}$ Taq polymerase (Fermentas), $1 \times$ PCR buffer, $1.5 \mathrm{mM} \mathrm{MgCl}_{2}, 0.2 \mathrm{mM}$ each dNTP, $0.8 \mu \mathrm{M}$ each primer and $2 \mu \mathrm{l}$ crude cell lysate, in a total volume of $50 \mu$ l. After $2 \mathrm{~min}$ at $94{ }^{\circ} \mathrm{C}$, samples were subjected to 30 cycles of amplification, $1 \mathrm{~min}$ at $94{ }^{\circ} \mathrm{C}, 1 \mathrm{~min}$ at $55{ }^{\circ} \mathrm{C}$ and 2 min at $72{ }^{\circ} \mathrm{C}$, and a final extension step of 2 min at $72{ }^{\circ} \mathrm{C}$. The nucleotide sequences of the $16 \mathrm{~S}$ rRNA, $r p o B$ and $g y r B$ genes were compared with reference sequences available in the GenBank/EMBL/DDBJ database using BLAST from NCBI (http://www.ncbi.nlm.nih.gov). Sequence analyses were conducted using the software MEGA 4.0 (Tamura et al., 2007). Sequence similarities were estimated based on the model of Jukes \& Cantor (1969) and dendrograms of estimated phylogenetic relationships were created using the neighbourjoining and maximum-parsimony methods. For dendrogram construction, non-homologous and ambiguous nucleotide positions were excluded from the calculations.

$16 \mathrm{~S}$ rRNA gene sequence analysis showed the affiliation of strains $\mathrm{G} 30^{\mathrm{T}}$ and A1PC16 to the genus Acinetobacter. This result was supported by the chemotaxonomic characterization. As described for the genus Acinetobacter (Collins \& Jones, 1981), strains $\mathrm{G} 30^{\mathrm{T}}$ and A1PC16 contained ubiquinones Q-8 and Q-9 as the major respiratory quinones, respectively representing 14 and $86 \%$ in strain $\mathrm{G} 30^{\mathrm{T}}$ and 12 and $88 \%$ in strain A1PC16. The G+C content of the genomic DNA of strains $\mathrm{G} 30^{\mathrm{T}}$ and $\mathrm{A} 1 \mathrm{PC} 16$ was within the range observed for this genus (38-47 mol\%) (Juni, 2005), with values of $39.3 \pm 0.05$ and $39.7 \pm 0.12 \mathrm{~mol} \%$, respectively. In the cellular fatty acid compositions of strains $\mathrm{G} 30^{\mathrm{T}}$ and A1PC16, as well as those of the type strains of related species, the components $\mathrm{C}_{18: 1} \omega 9 c$, summed feature 3 $\left(\mathrm{C}_{16: 1} \omega 7 c /\right.$ iso- $\left.\mathrm{C}_{15: 0} 2-\mathrm{OH}\right), \mathrm{C}_{16: 0}$ and $\mathrm{C}_{12: 0}$ predominated (Supplementary Table S1, available in IJSEM Online). The profile observed is consistent with the cellular fatty acid composition reported by Kämpfer (1993), particularly in the presence of $\mathrm{C}_{12: 0} 2-\mathrm{OH}$, supporting the inclusion of strains $\mathrm{G} 30^{\mathrm{T}}$ and A1PC16 in the genus Acinetobacter.

Strains $\mathrm{G}^{\mathrm{T}}{ }^{\mathrm{T}}$ and $\mathrm{A} 1 \mathrm{PC} 16$ shared $100 \% 16 \mathrm{~S}$ rRNA gene sequence similarity, suggesting that the two strains could be members of the same species. In fact, DNA-DNA hybridization between the two strains resulted in a value of 
$82.4 \%$ (reciprocal $95.6 \%$ ), above the threshold of $70 \%$ established by Wayne et al. (1987).

Although related to members of the genus Acinetobacter, strains $\mathrm{G} 30^{\mathrm{T}}$ and A1PC16 showed less than $97 \% 16 \mathrm{~S}$ rRNA gene sequence similarity to the type strains of all species of this genus with validly published names. Based on $16 \mathrm{~S}$ rRNA gene sequence similarity, the closest neighbours of strains $\mathrm{G} 30^{\mathrm{T}}$ and A1PC16 included the type strains of $A$. venetianus $(96.5 \%)$, A. guillouiae $(96.4 \%)$, A. bereziniae (96.3\%), A. radioresistens (96.0\%), A. junii (95.8\%), A. baumannii (95.8\%), A. calcoaceticus (95.5\%), A. johnsonii (95.4\%) and A. baylyi (95.2\%). The highest 16S rRNA gene sequence similarities were below $97 \%$, confirming our initial hypothesis that the isolates under study could not be affiliated to any species of the genus Acinetobacter with a validly published name (Fig. 1). It has been extensively argued and demonstrated that organisms sharing less than $97 \%$ 16S rRNA gene sequence similarity will yield DNA-DNA hybridization values lower than $60 \%$ (Stackebrandt \& Goebel, 1994; Vandamme et al., 1996; Stackebrandt \& Ebers, 2006) and thus cannot be considered members of the same species. Hence, DNA-DNA hybridizations with other members of the genus were not necessary in this case. The relationship of strains $\mathrm{G} 30^{\mathrm{T}}$ and A1PC16 with species with validly published names and genomic species of the genus Acinetobacter was also assessed on the basis of the comparison of partial $r p o B$ and $g y r B$ gene sequences; the usefulness of these sequences in species definition in the genus Acinetobacter has been demonstrated previously (Yamamoto et al., 1999; La Scola et al., 2006). The constructed dendrograms included the type strains of the species of the genus and representatives of different genomic species (Figs 2 and 3). Both of these analyses demonstrated that the proposed novel species forms a distinct lineage within the genus Acinetobacter. Strains $\mathrm{G}^{\mathrm{T}} 0^{\mathrm{T}}$ and A1PC16 shared less than 85 and $82 \%$ sequence similarity, respectively, for the genes $r p o B$ and gyrB, with the type strains of species with validly published names and strains of the different genomic species. In contrast, identity of 99.8 and $99.3 \%$, respectively, for the partial $r p o B$ and $g y r B$ gene sequences was observed between strains $\mathrm{G} 30^{\mathrm{T}}$ and A1PC16. These analyses confirmed the results of $16 \mathrm{~S}$ rRNA gene sequence comparison, consistently showing that strains $\mathrm{G} 30^{\mathrm{T}}$ and A1PC16 form a distinct clade within the genus Acinetobacter (Figs 1, 2 and 3).

Strains $\mathrm{G} 30^{\mathrm{T}}$ and A1PC16 and the type strains of closely related species were characterized in parallel in the current study (Table 1). Phenotypically, the non-haemolytic strains $\mathrm{G} 30^{\mathrm{T}}$ and A1PC16 were Gram-negative coccobacilli that were strictly aerobic, catalase-positive and oxidase-negative and non-motile, characteristic of the genus Acinetobacter (Juni, 2005). Despite being isolated from different habitats and in different regions, strains $\mathrm{G} 30^{\mathrm{T}}$ and $\mathrm{A} 1 \mathrm{PC} 16$ responded similarly to all the phenotypic tests performed. These strains could be distinguished from the other type strains examined in this study by the inability to assimilate L-proline. Other distinctive traits determined in this study included the following: from A. venetianus CCUG $45561^{\mathrm{T}}$, assimilation of L-arginine, 2,3-butanediol, phenylacetate, L-phenylalanine, lactic acid, 3-hydroxybutyric acid and 4-hydroxybenzoic acid

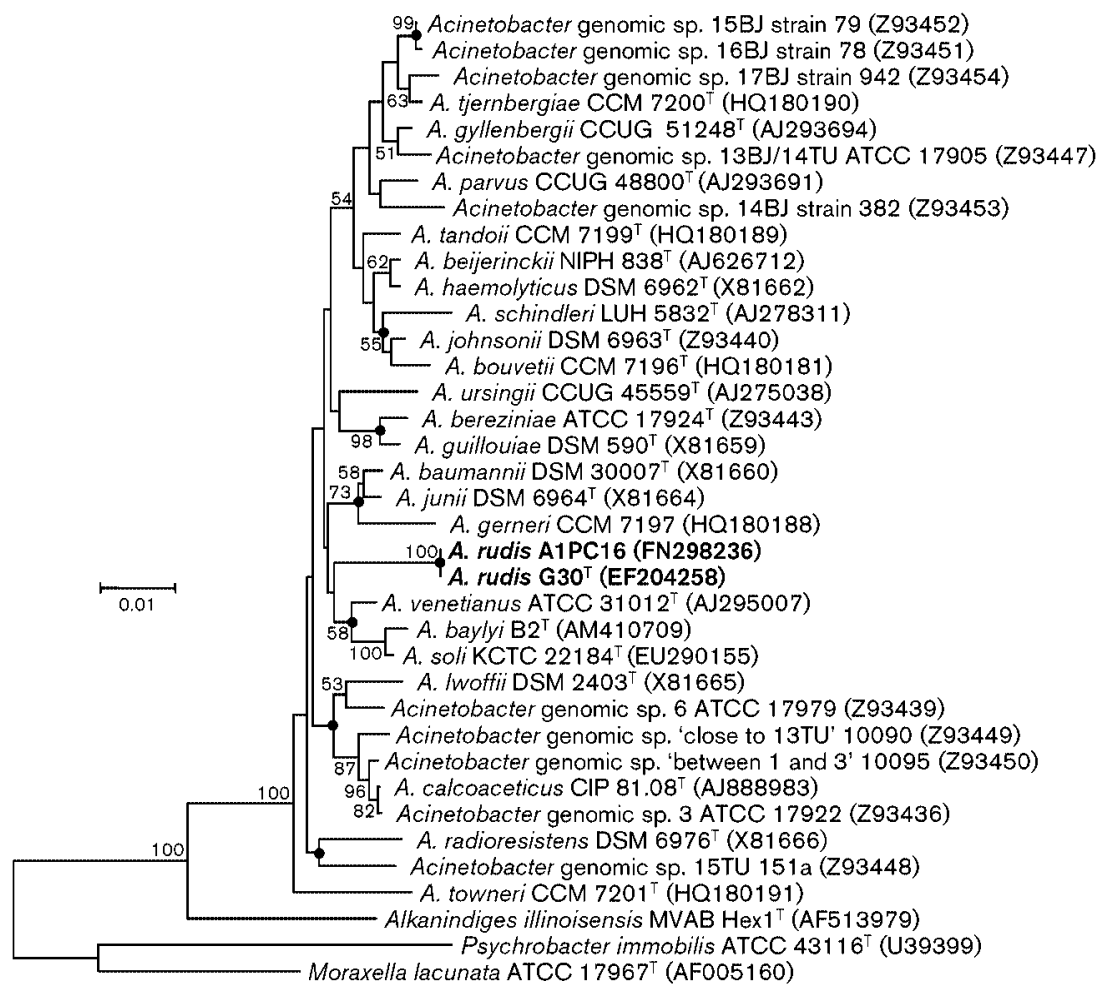

Fig. 1. Rooted tree based on $16 \mathrm{~S}$ rRNA gene sequences, showing the nearest neighbours of strains $\mathrm{G}_{30}{ }^{\top}$ and $\mathrm{A} 1 \mathrm{PC} 16$. The region used corresponds to positions 100-1423 (Escherichia coli numbering). The tree was generated by the neighbour-joining method. The sequences of Psychrobacter immobilis ATCC $43116^{\top}$ and Moraxella lacunata ATCC $17967^{\top}$ were used as an outgroup. Bootstrap percentages, generated from 1000 resamplings, $\geqslant 50 \%$ are indicated at branch points. Filled circles indicate branches also recovered by the maximum-parsimony method. Bar, 1 substitution per 100 nucleotide positions. 


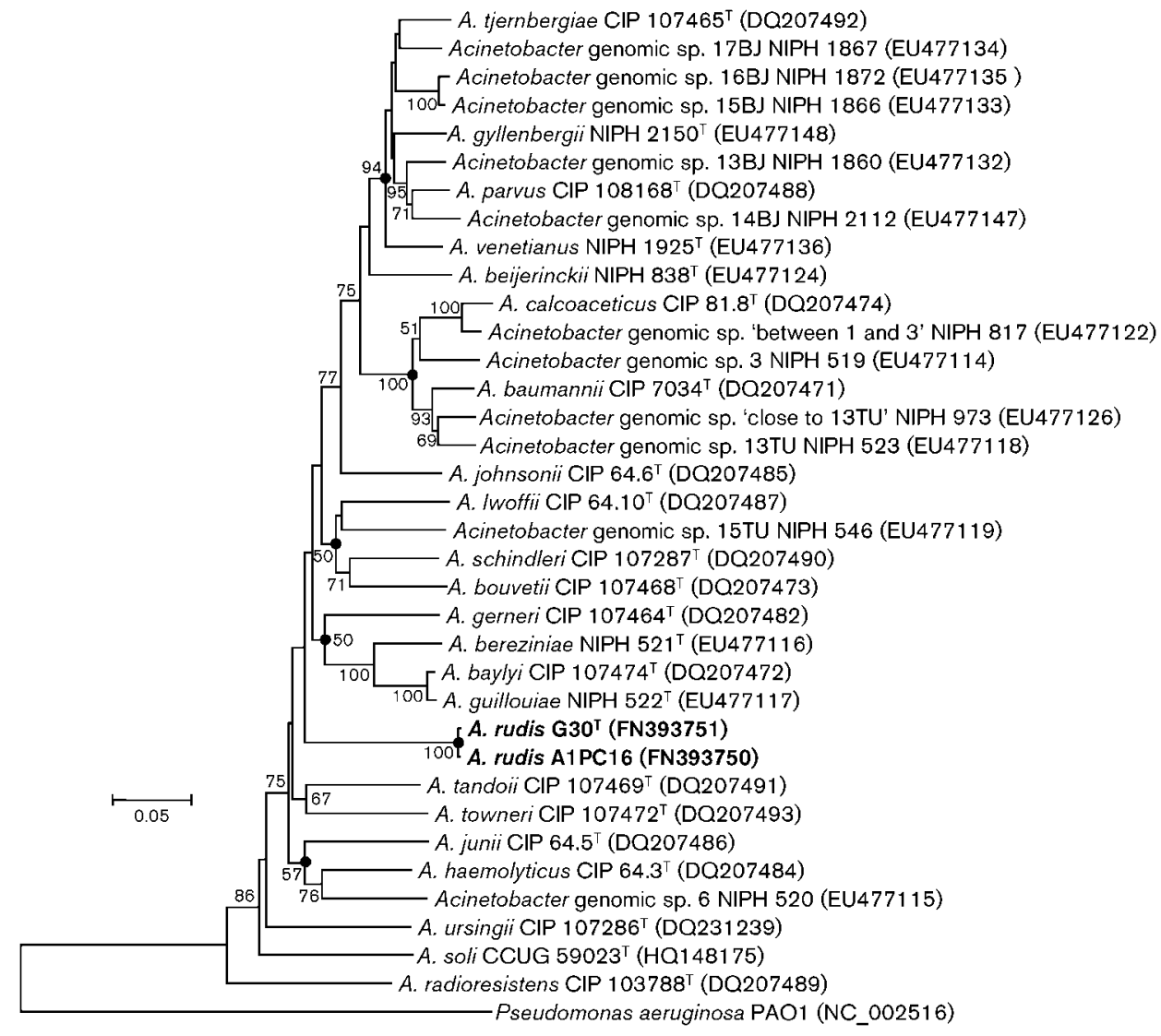

Fig. 2. Rooted tree based on concatenated $Z 1-Z 2$ regions of the rpoB gene, showing the nearest neighbours of strains $G 30^{\top}$ and A1PC16. The tree was generated by the neighbour-joining method. The sequence of $P$ seudomonas aeruginosa PAO1 was used as an outgroup. Bootstrap percentages, generated from 1000 resamplings, $\geqslant 50 \%$ are indicated at branch points. Filled circles indicate branches also recovered by the maximum-parsimony method. Bar, 5 substitutions per 100 nucleotide positions.

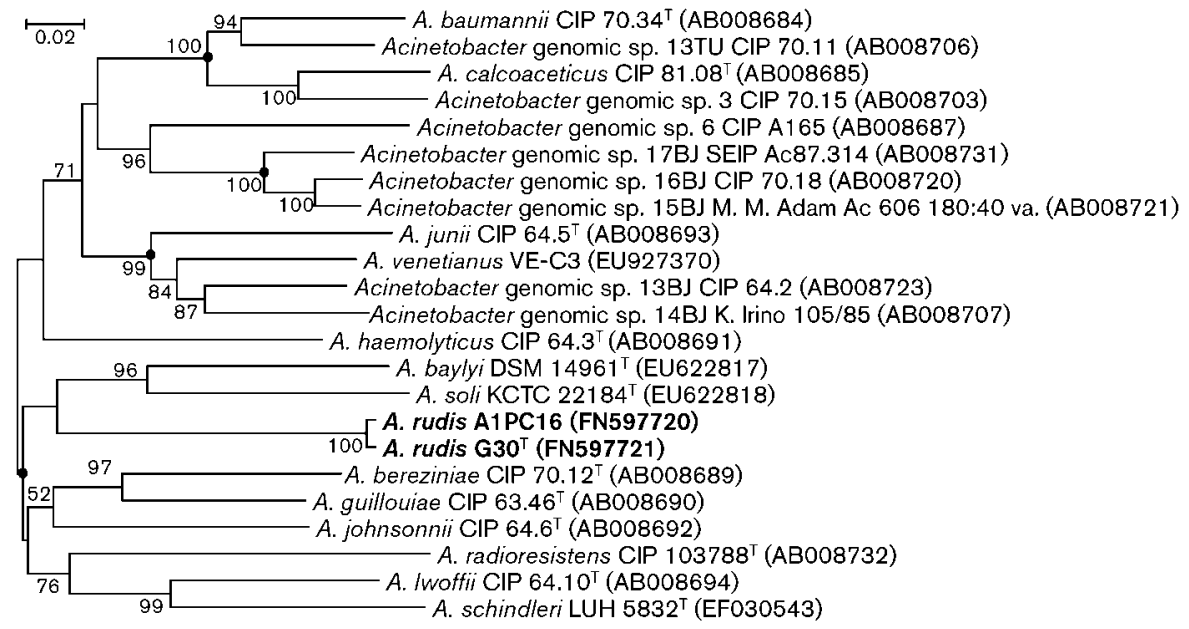

Fig. 3. Unrooted tree based on gyrB gene sequences, showing the nearest neighbours of strains $\mathrm{G} 30^{\top}$ and $A 1 P C 16$. Bootstrap percentages, generated from 1000 resamplings, $\geqslant 50 \%$ are indicated at branch points. Filled circles indicate branches also recovered by the maximum-parsimony method. Bar, 2 substitutions per 100 nucleotide positions. 
Table 1. Phenotypic characteristics that differentiate strains $G 30^{\top}$ and $A 1 P C 16$ from type strains of related species

Strains: 1, G30 ${ }^{\mathrm{T}}$; 2, A1PC16; 3, A. baumannii CCUG 19096 ; 4, A. baylyi CCUG 50765 ${ }^{\mathrm{T}}$; 5, A. bereziniae LMG 1003 ${ }^{\mathrm{T}}$; 6, A. calcoaceticus CCUG $12804^{\mathrm{T}}$; 7, A. guillouiae LMG $988^{\mathrm{T}}$; 8, A. johnsonii CCUG $19095^{\mathrm{T}}$; 9, A. junii CCUG $889^{\mathrm{T}}$; 10 , A. radioresistens CCUG $56440^{\mathrm{T}}$; 11 , A. venetianus CCUG $45561^{\mathrm{T}}$. All strains were tested in parallel in this study. None of the following sole carbon sources was assimilated by any of the tested strains: L-rhamnose, $\mathrm{N}$-acetylglucosamine, inositol, sucrose, maltose, itaconic acid, potassium 2-ketogluconate, potassium 5-ketogluconate, glycogen, 3-hydroxybenzoic acid, L-serine, D-mannitol, salicin, melibiose, L-fucose and D-sorbitol. All strains assimilated sodium acetate. W, Weakly positive.

\begin{tabular}{|c|c|c|c|c|c|c|c|c|c|c|c|}
\hline Characteristic & 1 & 2 & 3 & 4 & 5 & 6 & 7 & 8 & 9 & 10 & 11 \\
\hline Acid from glucose & - & - & + & + & $+^{*}$ & $-\dagger$ & - & - & - & - & - \\
\hline Adipate & - & - & + & + & $+^{\star}$ & + & + & - & - & $+^{*}$ & - \\
\hline L-Alanine & + & + & + & + & + & + & + & + & + & - & + \\
\hline L-Arginine & - & - & + & $-\dagger$ & - & + & - & $+^{*}$ & + & + & + \\
\hline 2,3-Butanediol & + & + & + & + & + & + & + & $-^{*}$ & - & - & - \\
\hline Capric acid $\ddagger$ & + & + & + & + & + & - & $\mathrm{w}$ & + & + & - & + \\
\hline Citrate & + & $\mathrm{w}$ & + & + & + & - & + & - & + & - & + \\
\hline Ethanol & + & + & + & + & + & + & + & + & $+^{\star}$ & $-\dagger$ & + \\
\hline D-Glucose & - & - & - & + & - & - & - & - & - & - & - \\
\hline L-Leucine & $\mathrm{w}$ & $\mathrm{w}$ & + & - & - & $-^{*}$ & - & - & $-^{\star}$ & + & + \\
\hline Phenylacetate & + & + & + & - & $-{ }^{*}$ & $-\dagger$ & $+^{*}$ & - & - & - & - \\
\hline L-Phenylalanine & + & + & + & - & - & + & - & - & - & $\mathrm{W}^{*}$ & - \\
\hline L-Proline & - & - & + & + & + & + & + & + & + & + & + \\
\hline Propionic acid $\ddagger$ & + & + & + & + & + & $\mathrm{w}$ & + & + & + & - & + \\
\hline Putrescine & - & - & + & - & - & + & - & - & - & + & - \\
\hline D-Ribose & - & - & + & - & - & - & - & - & - & - & - \\
\hline Sodium benzoate & + & + & + & + & + & - & + & + & + & $-\dagger$ & + \\
\hline Sodium malonate & + & + & + & + & - & $-\dagger$ & $-^{\star}$ & $-^{\star}$ & - & + & + \\
\hline Suberic acid & - & - & + & + & + & + & + & - & - & + & - \\
\hline Valeric acid $\neq$ & + & + & + & + & + & + & + & + & + & - & + \\
\hline
\end{tabular}

${ }^{\star}$ According to the literature, variable results for this test may be observed for members of this species.

$\dagger$ Result different from that described in the literature.

$\$$ Not tested previously in other studies.

and the absence of the fatty acids $\mathrm{C}_{17: 1} \omega 8 c$ and $\mathrm{C}_{17: 0}$; from A. guillouiae LMG $988^{\mathrm{T}}$, assimilation of adipate, L-aspartate, $\mathrm{L}$-phenylalanine and suberic acid and the proportions of the fatty acids $\mathrm{C}_{16: 0}, \mathrm{C}_{18: 1} \omega 9 c$ and $\mathrm{C}_{18: 1} \omega 7 c$, from $A$. bereziniae LMG $1003^{\mathrm{T}}$, assimilation of L-aspartate, L-leucine, L-phenylalanine, suberic acid and sodium malonate and lower proportions of the fatty acids $\mathrm{C}_{18: 1} \omega 9 c$ and $\mathrm{C}_{18: 1} \omega 7 c$. Other distinctive traits between strains $\mathrm{G} 30^{\mathrm{T}}$ and $\mathrm{A} 1 \mathrm{PC} 16$ and the type strains of closely related neighbours examined in this study are described in Table 1 and Supplementary Table S1.

The phenotypic traits determined in this study were, in general, in agreement with previous publications (Supplementary Table S2). On the basis of information obtained in the current study and in the literature for the 22 species of the genus Acinetobacter with validly published names, it is possible to suggest a path of identification of the proposed novel species. Thus, members of the proposed novel species can be identified (i.e. distinguished from all species of the genus with validly published names) as non-haemolytic, with the ability to assimilate 4-hydroxybenzoate, malonate, phenylacetate, L-histidine, L-leucine and phenylalanine, but not adipate, putrescine or L-aspartate, as single carbon sources. Together, the arguments stated above support the proposal of a novel species within the genus Acinetobacter, named Acinetobacter rudis sp. nov., represented by strains $\mathrm{G} 30^{\mathrm{T}}$ and A1PC16.

\section{Description of Acinetobacter rudis sp. nov.}

Acinetobacter rudis (ru'dis. L. adj. rudis, -is raw, not processed; N.L. gen. n. rudis of/from raw unprocessed products). 
Colonies are white, circular, convex and smooth after $24 \mathrm{~h}$ of incubation on PCA. Cells are Gram-negative, strictly aerobic, non-motile coccobacilli $(0.56 \pm 0.10 \mu \mathrm{m}$ diameter $)$. Catalase-positive and oxidase-negative. Growth occurs at $10-37^{\circ} \mathrm{C}, \mathrm{pH} 5.0-9.5$ and in the presence of up to $3 \% \mathrm{NaCl}$. After 7 days of incubation, no growth is observed at 6 or $40{ }^{\circ} \mathrm{C}$ or in the presence of $5 \% \mathrm{NaCl}$. Growth does not occur in an anaerobic atmosphere and nitrate is not reduced. Haemolysis is not observed. Utilization of Simmons' citrate (growth) is positive. Aesculin is not hydrolysed. $\mathrm{H}_{2} \mathrm{~S}$ and indole are not produced. Glucose is not fermented. Acid is not produced from glucose. Produces the enzymes alkaline and acid phosphatase, esterase $\mathrm{C} 4$, esterase lipase $\mathrm{C} 8$, leucine arylamidase and naphthol-AS-BI-phosphohydrolase; produces valine and cystine arylamidases weakly. The enzymes $\alpha$ - and $\beta$-galactosidase, arginine dihydrolase, lysine and ornithine decarboxylase, urease, tryptophan deaminase, gelatinase, lipase (C14), trypsin, $\alpha$-chymotrypsin, $\beta$-glucuronidase, $\alpha$ - and $\beta$-glucosidase, $N$-acetyl- $\beta$-glucosaminidase, $\alpha$-mannosidase and $\alpha$-fucosidase are not produced. Sole carbon sources assimilated include L-malate, citrate, phenylacetate, sodium malonate, sodium acetate, L-alanine, L-histidine, ethanol, sodium benzoate, 2,3-butanediol, Lphenylalanine and propionic, lactic, capric, valeric, 3hydroxybutyric and 4-hydroxybenzoic acids. L-Leucine is assimilated weakly after $48 \mathrm{~h}$ of incubation. Carbon sources not assimilated include D-glucose, L-arabinose, D-mannose, D-mannitol, $\mathrm{N}$-acetylglucosamine, maltose, potassium gluconate, adipate, L-rhamnose, D-ribose, inositol, sucrose, itaconic acid, suberic acid, potassium 5-ketogluconate, glycogen, 3-hydroxybenzoic acid, L-serine, salicin, melibiose, L-fucose, D-sorbitol, potassium 2-ketogluconate, L-proline, L-arginine, putrescine, L-aspartate and histamine. The predominant cellular fatty acids are $\mathrm{C}_{16: 0}, \mathrm{C}_{18: 1} \omega 9 c$ and $\mathrm{C}_{16: 1} \omega 7 c /$ iso- $\mathrm{C}_{15: 0} 2-\mathrm{OH}$ and the major respiratory quinones are ubiquinones Q-9 and Q-8. The genomic DNA $\mathrm{G}+\mathrm{C}$ content is $39-40 \mathrm{~mol} \%$.

Strain $\mathrm{G}^{\mathrm{T}}{ }^{\mathrm{T}}\left(=\mathrm{LMG} 26107^{\mathrm{T}}=\right.$ CCUG $57889^{\mathrm{T}}=\mathrm{DSM}$ $24031^{\mathrm{T}}=$ CECT $\left.7818^{\mathrm{T}}\right)$ is the type strain, isolated from raw milk.

\section{References}

Ben-Ze'ev, I. S., Levy, E., Eilam, T. \& Anikster, Y. (2005). Whole-cell fatty acid profiles - a tool for species and subspecies classification in the Puccinia recondita complex. J Plant Pathol 87, 187-197.

Carr, E. L., Kämpfer, P., Patel, B. K. C., Gürtler, V. \& Seviour, R. J. (2003). Seven novel species of Acinetobacter isolated from activated sludge. Int J Syst Evol Microbiol 53, 953-963.

Collins, M. D. \& Jones, D. (1981). Distribution of isoprenoid quinone structural types in bacteria and their taxonomic implications. Microbiol Rev 45, 316-354.

Cruze, J. A., Singer, J. T. \& Finnerty, W. R. (1979). Conditions for quantitative transformation in Acinetobacter calcoaceticus. Curr Microbiol 3, 129-132.

Euzéby, J. P. (1997). List of Bacterial Names with Standing in Nomenclature: a folder available on the Internet. Int J Syst Bacteriol 47, 590-592.
Ferreira da Silva, M., Vaz-Moreira, I., Gonzalez-Pajuelo, M., Nunes, O. C. \& Manaia, C. M. (2007). Antimicrobial resistance patterns in Enterobacteriaceae isolated from an urban wastewater treatment plant. FEMS Microbiol Ecol 60, 166-176.

Gennari, M. \& Stegagno, F. (1985). [Isolation and characterization of Acinetobacter calcoaceticus from fresh, frozen and ice-stored fish products]. Microbiol Alim Nutr 3, 247-259 (in Italian).

Gennari, M. \& Stegagno, F. (1986). Isolation and characterization of Acinetobacter calcoaceticus from raw, washed and frozen vegetables. Arch Vet Ital 37, 131-137.

Hantsis-Zacharov, E. \& Halpern, M. (2007). Culturable psychrotrophic bacterial communities in raw milk and their proteolytic and lipolytic traits. Appl Environ Microbiol 73, 7162-7168.

Jukes, T. H. \& Cantor, C. R. (1969). Evolution of protein molecules. In Mammalian Protein Metabolism, vol. 3, pp. 21-132. Edited by H. N. Munro. New York: Academic Press.

Juni, E. (2005). Genus II. Acinetobacter Brisou and Prévot 1954, $727^{\mathrm{AL}}$. In Bergey's Manual of Systematic Bacteriology, 2nd edn, vol. 2B, pp. 425-437. Edited by D. J. Brenner, N. R. Krieg \& J. T. Stanley. New York: Springer.

Kämpfer, P. (1993). Grouping of Acinetobacter genomic species by cellular fatty acid composition. Med Microbiol Lett 2, 394-400.

La Scola, B., Gundi, V. A. K. B., Khamis, A. \& Raoult, D. (2006). Sequencing of the $r p o B$ gene and flanking spacers for molecular identification of Acinetobacter species. J Clin Microbiol 44, 827-832.

Marmur, J. (1961). A procedure for the isolation of deoxyribonucleic acid from micro-organisms. J Mol Biol 3, 208-218.

Mesbah, M., Premachandran, U. \& Whitman, W. B. (1989). Precise measurement of the $\mathrm{G}+\mathrm{C}$ content of deoxyribonucleic acid by highperformance liquid chromatography. Int J Syst Bacteriol 39, 159-167.

Munsch-Alatossava, P. \& Alatossava, T. (2006). Phenotypic characterization of raw milk-associated psychrotrophic bacteria. Microbiol Res 161, 334-346.

Murray, R. G. E., Doetsch, R. N. \& Robinow, F. (1994). Determinative and cytological light microscopy. In Methods for General and Molecular Bacteriology, pp. 21-41. Edited by P. Gerhardt, R. G. E. Murray, W. A. Wood \& N. R. Krieg. Washington, DC: American Society for Microbiology.

Nemec, A., Musílek, M., Maixnerová, M., De Baere, T., van der Reijden, T. J. K., Vaneechoutte, M. \& Dijkshoorn, L. (2009). Acinetobacter beijerinckii sp. nov. and Acinetobacter gyllenbergii sp. nov., haemolytic organisms isolated from humans. Int J Syst Evol Microbiol 59, 118-124.

Novo, A. \& Manaia, C. M. (2010). Factors influencing antibiotic resistance burden in municipal wastewater treatment plants. Appl Microbiol Biotechnol 87, 1157-1166.

Smibert, R. M. \& Krieg, N. R. (1994). Phenotypic characterization. In Methods for General and Molecular Bacteriology, pp. 611-651. Edited by P. Gerhardt, R. G. E. Murray, W. A. Wood \& N. R. Krieg. Washington, DC: American Society for Microbiology.

Stackebrandt, E. \& Ebers, J. (2006). Taxonomic parameters revisited: tarnished gold standards. Microbiol Today 33, 152-155.

Stackebrandt, E. \& Goebel, B. M. (1994). Taxonomic note: a place for DNA-DNA reassociation and $16 \mathrm{~S}$ rRNA sequence analysis in the present species definition in bacteriology. Int J Syst Bacteriol 44, 846849.

Tamura, K., Dudley, J., Nei, M. \& Kumar, S. (2007). MEGA4: molecular evolutionary genetics analysis (MEGA) software version 4.0. Mol Biol Evol 24, 1596-1599.

Tindall, B. J. (1989). Fully saturated menaquinones in the archaebacterium Pyrobaculum islandicum. FEMS Microbiol Lett 60, 251-254. 
Uraz, G. \& Citak, S. (1998). The isolation of Pseudomonas and other Gram (-) psychrotrophic bacteria in raw milks. J Basic Microbiol 38, 129-134.

Vandamme, P., Pot, B., Gillis, M., De Vos, P., Kersters, K. \& Swings, J. (1996). Polyphasic taxonomy, a consensus approach to bacterial systematics. Microbiol Rev 60, 407-438.

Vaneechoutte, M., Nemec, A., Musílek, M., van der Reijden, T. J., van den Barselaar, M., Tjernberg, I., Calame, W., Fani, R., De Baere, T. \& Dijkshoorn, L. (2009). Description of Acinetobacter venetianus ex Di Cello et al. 1997 sp. nov. Int J Syst Evol Microbiol 59, 1376-1381.

Vaz-Moreira, I., Nobre, M. F., Nunes, O. C. \& Manaia, C. M. (2007) Gulbenkiania mobilis gen. nov., sp. nov., isolated from treated municipal wastewater. Int J Syst Evol Microbiol 57, 1108-1112.
Wayne, L. G., Brenner, D. J., Colwell, R. R., Grimont, P. A. D., Kandler, O., Krichevsky, M. I., Moore, L. H., Moore, W. E. C., Murray, R. G. E. \& other authors (1987). Report of the ad hoc committee on reconciliation of approaches to bacterial systematics. Int J Syst Bacteriol 37, 463464.

Yamamoto, S., Bouvet, P. J. M. \& Harayama, S. (1999). Phylogenetic structures of the genus Acinetobacter based on gyrB sequences: comparison with the grouping by DNA-DNA hybridization. Int J Syst Bacteriol 49, 87-95.

Ziemke, F., Höfle, M. G., Lalucat, J. \& Rosselló-Mora, R. (1998). Reclassification of Shewanella putrefaciens Owen's genomic group II as Shewanella baltica sp. nov. Int J Syst Bacteriol 48, 179186. 